UDK 664.951.037.5-027.38:[664.9.022+664.29]:005.336.3

T. Manoli, A. Gerasim, N. Kushnirenko, T. Nikitchina

Odessa National Academy of Food Technologies, 112 Kanatnaya str., Odessa, 65082, Ukraine

\title{
THE INFLUENCE OF PRE-TREATMENT AND LOW-ESTERIFIED PECTINE SUBSTANCES ON QUALITY OF FROZEN FISHERY SEMIFINISHED PRODUCTS
}

\begin{abstract}
Ability of a mixture of low-esterified pectin and acid to cause structural changes of mesopelagic small fish proteins is determined. These changes lead to a decrease in the MRP and an increase in water yielding. Such a influence mechanism on the moisture index rate can be used for directional control of the process of fish semi-finished products freezing. The optimal modes of polysaccharide-acidic treatment of muscle tissue are developed for Baltic sprat, Black Sea sprat, as well as for haarder. The researched pretreatment allowing to obtain frozen fish semi-finished products with high organoleptic properties.
\end{abstract}

Keywords: Solutions of organic acids; Pectin; Mesopelagic fish; Freezing; Water yielding; Organoleptic properties.

\section{Т. А. Маноли, А. С. Герасим, Н. М. Кушниренко, Т. И. Никитчина}

Одесская национальная академия пищевых технологий, ул. Канатная 112, г. Одесса, 65039, Украина

\section{ВЛИЯНИЕ ПРЕДВАРИТЕЛЬНОЙ ОБРАБОТКИ И НИЗКОЭТЕРИФИЦИРОВАННЫХ ПЕКТИ- НОВЫХ ВЕЩЕСТВ НА КАЧЕСТВО ЗАМОРОЖЕННЫХ РЫБНЫХ ПОЛУФАБРИКАТОВ}

\begin{abstract}
В данной работе установлена способность смеси из низкоэтерифицированного пектина и кислоты вызывать структурные изменения белков мелких мезопелангических рыб, ведущие к уменьшению ВУС и увеличению влагоотдачи. Такой механизм влияния на показатель влагосодержания может быть использован для направленного регулирования прочесса замораживания рыбного полуфабриката. Получены оптимальные режимы проведения полисахаридно-кислотной обработки мышечной ткани кильки балтийской и черноморской, а также пиленгаса. Исследованная предварительная обработка позволяет получать замороженные рыбные полуфабрикаты с высокими органолептическими свойствами.
\end{abstract}

Ключевые слова: Органические кислоты; Низкоэтерифицированный пектин; Мезопелангические рыбы; Замораживание; Влагоотдача; Органолептические свойства

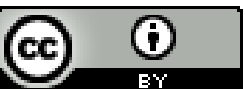

This work is licensed under the Creative Commons Attribution International License (CC BY).

http://creativecommons.org/licenses/by/4.0/

\section{INTRODUCTION}

Solving the problem of dehydration of fish muscle tissue for technological needs in the production of frozen fish semi-products is possible through redeployment of the forms of bonds of moisture with proteins of muscle tissue of fish.

Muscle tissue of fish can be seen as a complex polydisperse system in which water is the dispersion medium and dispersed phase includes a large number of organic and inorganic substances. In various parts of the tissue composition of the aqueous solution may be different, such as in cells and intercellular spaces.

In the muscle tissue of fish moist is divided among bundles of fibers, the individual fibers and the fibers themselves. Fiber shells and bundles also contain moisture. Moisture amount that lies in various parts of the muscle is not equal, the largest amount is revealed between the bundles of fibers [1].

According to the widely accepted classification of bonding forms of moisture with the material, proposed by P.A. Rebinder, there are distinguished: the chemical bond, physicochemical bond, and mechanical bond.
Due to the chemical or physicochemical bond between water and matter, about $70 \%$ of the water is associated with myofibril tissue proteins.

Other classification of water and material bond, proposed by H.B. Chizhov, divides it on structural-free and bound [2].

Bound water (ion or hydrational) is firmly held with mostly proteins, and other substances with the hydrophilic group of proteins: carboxyl, amine, carbonyl and phenol.

The interaction between the dipoles of water and protein hydrophilic centers forms hydrogen bonds [3].

According to the existing notions fish meat can be seen as colloidal or capillary-porous body of a complex structure. The basis of this body is a structural mesh of proteins that are at swollen state, which include viscous solutions. They hold soluble proteins, nitrogen and mineral substances with hydrophilic properties. Bound water is held firmly enough with protein, its dielectric constant is close to zero, it has no solvent capacity, does not freeze at low temperatures.

Protein substances in the water environment are multivalent amphoteric electrolytes, because the nature of 
their interaction with water depends on the active reaction of the medium.

In minimal hydration in animal tissues is observed in protein isoelectric state where acidic and basic groups of protein molecules mutually blocked, and their role is played by other hydrophilic polar groups (cysteine, serine, tyrosine) [4].

Isoelectric point of most proteins in muscle fibers, which determines the nature of the transformation of proteins in the process of fish treatment is located within 5,2$5,5 \mathrm{pH}$ [3]. According to some researchers, the isoelectric point is at $\mathrm{pH} 4-4,5$. On the isoelectric point is related to the ability of protein hydration and dissolution; change in $\mathrm{pH}$ leads to a decrease or increase hydration and solubility of proteins [6].

Bound water does not play a significant role in the biochemical processes that occur in the muscle tissue. The removal of bound water from the muscle tissue of fish is needed to break its relationship with fibers by heating the meat, add it to the electrolytes or other methods that cause conformational changes in proteins and weaken hydrophilic substances. The binding of water with protein or other hydrophilic substance changes its physical properties that should be considered during the scientific substantiation of the processing of fish [2].

\section{MAIN PART}

Previous heat treatment that is performed in the production of various kinds of canned food is aimed to remove the moisture (20\%), along with other major tasks.
The reduction of the loss of nutrients and improvement of the quality of canned goods is possible through using of organic and inorganic acids as pre-treatment and bringing in of low-esterified pectin. This allows to reduce processing time in several times, and preserve the organoleptic properties of native materials with significant energy savings.

The goal is achieved with using a mixture solution of hydrochloric acid and pectin for processing and bringing $\mathrm{pH}$ of muscle tissue to isoelectric point values of most of muscle proteins of mesopelagic fish, which leads to a redistribution of forms of moisture proteins bonds [3].

As an indicator of the degree of change in the properties of the muscle-polysaccharide acid treatment, using water-retaining capacity of muscle tissue (MRP).

The proposed technology is based on the properties of biological polymers to retain moisture. While processing electrolyte polar molecules get covered with protein hydration shell. Changing the structure of muscle tissue reduces the number of immobilized moisture and increase free moisture.

Affecting the proteins of muscle tissue with polysaccharide-acid mixture causes the diffusion of ions in the electrolyte object tissue, water molecules diffuse from fish meat in an electrolyte solution, which explains the decrease in the total amount of moisture in the product and prevent losses during unfreezing fish semis .

The proposed method effects as follows, allowing to realize preliminary processing of semi-finished product and to reduce weight by $20 \%$ (Fig. 1).

\section{Small mesopelagic fish}

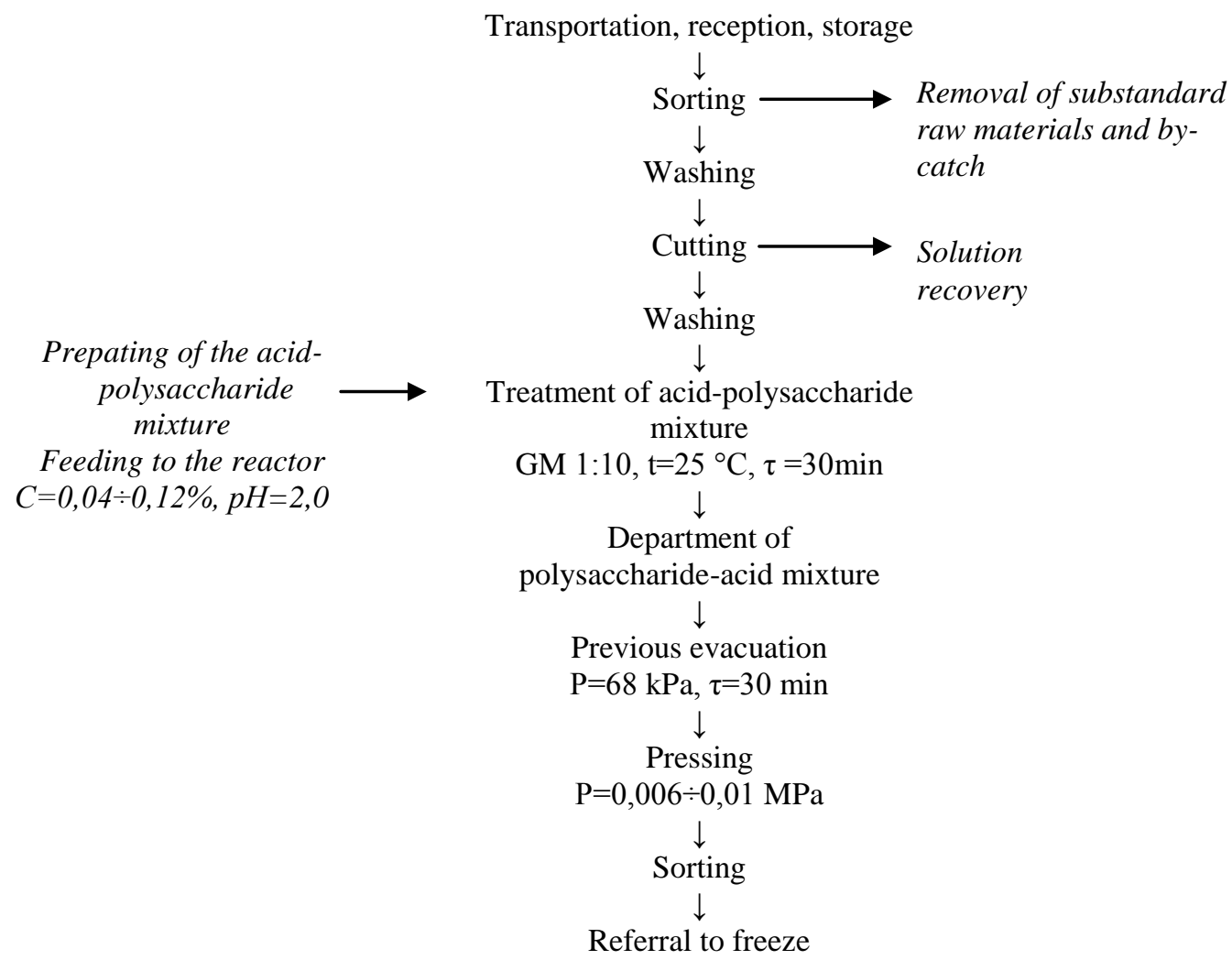

Figure 1 - Technological scheme of pretreatment fish with polysaccharide-acid mixture 
The experimentally set processing parameters are: temperature processing $(\mathrm{t})$, processing time $(\tau)$, hydrological module (GM), and the concentration of polysaccharide-acid mixture $(\mathrm{C})$.

Table 1 - Parameters of process of fish muscle tissue dehydration

\begin{tabular}{|c|c|c|c|c|c|c|c|}
\hline $\begin{array}{c}\text { Initial muscle } \\
\mathrm{pH}\end{array}$ & $\begin{array}{c}\text { Initial PAM } \\
\mathrm{pH}\end{array}$ & $\begin{array}{c}\text { PAM } \\
\text { concentration, } \\
\mathrm{C}, \%\end{array}$ & $\begin{array}{c}\text { duration of } \\
\text { exposure, } \\
\tau, \text { min. }\end{array}$ & $\begin{array}{c}\text { ratio of fish } \\
\text { and PAM, } \\
\mathrm{GM}\end{array}$ & $\begin{array}{c}\text { exposure } \\
\text { temperature, } \\
\mathrm{t},{ }^{\circ} \mathrm{C}\end{array}$ & $\begin{array}{c}\text { final } \mathrm{pH} \text { of the } \\
\text { current PAM } \\
\text { solution }\end{array}$ & $\begin{array}{c}\text { final } \mathrm{pH} \text { of } \\
\text { muscle tissue }\end{array}$ \\
\hline 6,8 & 2,3 & 0,04 & 25 & $1: 6$ & 25 & 3,35 & 5,84 \\
6,8 & 2,3 & 0,04 & 30 & $1: 10$ & 25 & 3,65 & 5,2 \\
\hline 6,8 & 2,4 & 0,035 & 25 & $1: 6$ & 25 & 3,3 & 5,85 \\
6,8 & 2,4 & 0,035 & 30 & $1: 10$ & 25 & 3,95 & 5,2 \\
\hline 6,8 & 2,5 & 0,031 & 25 & $1: 6$ & 25 & 3,55 & 6,2 \\
6,8 & 2,5 & 0,031 & 30 & $1: 10$ & 25 & 3,6 & 5,35 \\
\hline
\end{tabular}

For organoleptic characteristics semi-product has the following characteristics (Table 2).

Table 2 - Organoleptic indexes of semi-products

\begin{tabular}{|c|c|c|}
\hline Indexes & $\begin{array}{c}\text { The con- } \\
\text { tent of } \\
\text { ions } \mathrm{Cl}^{-} \text {, } \\
\%\end{array}$ & Semi-product characteristics \\
\hline $\begin{array}{l}\text { Taste and } \\
\text { smell } \\
\text { Muscle } \\
\text { tissue color } \\
\text { Consist- } \\
\text { ence }\end{array}$ & 0,17 & $\begin{array}{l}\text { The coverlet is integral, with a } \\
\text { strong guanine color. Uniform } \\
\text { canopy, without large gaps. } \\
\text { Pleasant, typical fish, do not } \\
\text { feel sour taste. } \\
\text { Bleached, inherent heat- } \\
\text { treated muscle. } \\
\text { Elastic, from } 50 \text { to } 100 \mathrm{~g} \text { pen- } \\
\text { etrometer effort that meets the } \\
\text { soft tender consistency. }\end{array}$ \\
\hline
\end{tabular}

As a result of the impact occurred changes of proteins (denaturation), which leads to increased muscle water yielding. This indicator reached the limits stipulated by the technological instructions for frozen food.

We have tested several variants of solutions with small values of acceptable concentration of 0,04 to $0,12 \%$. The studies showed that when all things being equal, the change in concentration at this level has no significant impact on the MRP.

The study of polysaccharide-acid treatment of other species of fish, soiuy mullet, showed that our proposed method is selective and its use is conditioned by species and morphological features of raw materials and features of chemical composition. A distinctive feature of the target species is high moisture capacity in muscle tissue (80\% moisture) and weakened structure of muscle tissue, which prevents its use in the manufacture of frozen semiproducts. It is shown that under the same conditions, the mass fraction of moisture loss while acidic polysaccharide-processing for the Black Sea and Baltic sprat ranged from $6.4 \%$ to $33 \%$ with a slight increase in MRP, but for so-iuy mullet observed a slight decrease in weight, and in some cases, significant swelling of the muscle tissue and sustained increase in mass, which is caused by the difference in the composition of myofibrillar and sarcoplasmic proteins of the objects, various fishing season, rigor mortis time.
In order to establish the optimum $\mathrm{pH}$ of action polysaccharide-acid mixture (PAM) dehydration process was carried out at different values (Table 1).
Studies of the so-iuy mullet protein fraction showed that the muscle tissue of the target species is much less salt-soluble protein than other species.

\section{CONCLUSIONS}

The results of microbiological studies found that treatment with acid-polysaccharide mixture leads to a decrease of the probability of specific corruption agents development in fish semi-products after unfreezing. This is primarily due to the decrease in the number of free moisture - the main factor of growth of any microorganisms, in addition, lowering the $\mathrm{pH}$ of the surface layers of fish in the acidic polysaccharide-processing prevents contamination with spontaneous microflora. Such an effective influence on the spontaneous flora of new method semi-products is in line with the concept of scientific substantiation of thermal stabilization.

The resulting method was tested during freezing of semi-finished products with some of the prepolysaccharide acid processing, which had highly appreciated organoleptic characteristics and have appropriate documentation of physical and chemical indexes [4].

\section{REFERENCES}

1. Borisochkina L.I. (1998). Tehnologija produktov iz okeanicheskih ryb. M.: VO "Agropromizdat", 208 p.

2. Mizhueva S.A., Manuhin A.S. (1992). Vlijanie zamorazhivanija $\mathrm{v}$ rastvore hlorida kal'cija na kachestvo ryby. Sovershenstvovanie metodov holodil'nogo konservirovanija pishhevyh produktov. p. $62-67$.

3. Venger K.P. (1983). Racional'nye rezhimy zamorazhivanija tushek pticy $\mathrm{v}$ zhidkosti. Holodil'naja tehnika. № 3. p. 33 - 36 .

4. Bezusov A.T., Palamarchuk A.S., Titlov A.S., Manol T.A. (2003). Razrabotka tehnologii rassol'nogo zamorazhivanija ryby s ispol'zovaniem zashhitnyh pokrytij. Vestnik Mezhdunarodnoj akademii holoda. M., №3. p. 29 -33 . 
Т. А. Манолі, Г. С. Герасим, Н. М. Куиніренко, Т. І. Нікімчіна

Одеська національна академія харчових технологій, вул. Канатна 112, м. Одесса, 65039, Україна

\section{ВПЛИВ ПОПЕРЕДНЬОЇ ОБРОБКИ ТА НИЗЬКОЕТЕРИФІКОВАНИХ ПЕКТИНОВИХ РЕЧОВИН НА ЯКІСТЬ ЗАМОРОЖЕНИХ РИБНИХ НАПІВФАБРИКАТІВ}

У роботі встановлена здатність суміші з низькоетерифікованим пектином і кислоти викликати структурні зміни білків дрібних мезопелангічних риб, щзо веде до зменшення ВУС і збільшення вологовіддачі. Незважаючи на значну кількість з'єднань, що викликають зміну конформаџіi (денатураџію) білків, вибір таких хімічних модифікантів для використання їх при виробництві продуктів з регульованим вологовмістом дуже обмежений, тому щзо головною характеристикою цих з'єднань повинна бути абсолютна нешкідливість для організму людини. Такий механізм впливу на показник вмісту вологи може бути використано для спрямованого регулювання процесу заморожування рибного напівфабрикату. Отримано оптимальні режими проведення полісахаридно-кислотної обробки м'язової тканини кільки балтійської і чорноморської, а також піленгаса. Опрацьована попередня обробка дозволяє отримувати заморожені рибні напівфабрикати з високими органолептичними властивостями. Вплив хімічних речовин дозволив домогтися позитивного результату, а саме скоротити час обробки в десятки разів; витримати технологічний регламент, знизивши вміст вологи; домогтися значного підвищення соковитості зразків у порівнянні з традиційною обробкою. Отримані продукти з заданим вологовмістом при ефективному впливі на фізико-хімічні властивості води, зв'язаної білками, щзо пройшли конформаційні зміни під дією комбінованих факторів. При иььому ступінь гідратації білків зазнала значні зміни, щчо обумовлені кількістю і розподілом заряджених полярних і неполярних молярних груп між поверхневою і внутрішньою частиною молекул. Таким чином проведена попередня обробка дозволила варіювати співвідношення таких гідрофільних і гідрофобних радикалів на поверхні білка, впливаючи на його молекулярне оточення і викликаючи при цฺьому конформаційні зміни білкових молекул.

Ключові слова: Органічні кислоти; Низькоетерифікований пектин; Мезопелангічні риби; Заморожування; Вологовіддача; Органолептичні властивості.

\section{ЛІТЕРАТУРА}

1. Борисочкина Л.И. Технология продуктов из океанических рыб / Л.И. Борисочкина, - М.: ВО "Агропромиздат", 1998. - 208 с.

2. Мижуева С.А. Влияние замораживания в растворе хлорида кальция на качество рыбы / С.А. Мижуева, А.С. Манухин // Совершенствование методов холодильного консервирования пищевых продуктов. - 1992. - С. $62-67$.
3. Венгер К.П. Рациональные режимы замораживания тушек птицы в жидкости // Холодильная техника. - 1983. - № 3. - С. $33-36$.

4. Безусов А.Т. Разработка технологии рассольного замораживания рыбы с использованием защитных покрытий / А.Т. Безусов, А.С. Паламарчук, А.С. Титлов, Т.А. Маноли // Вестник Международной академии холода. - М., 2003. - №3. - С. 29 - 33.

Отримана в редакції 29.09.2016, прийнята до друку 01.11.2016 